\title{
Conservation Horticulture in Mango Orchards: Comparative Effects of Conventional and Conservation Management Practices on Soil Properties of an Alfisol under Seasonally Dry Tropical Savanna Climate
}

\author{
A. N. Ganeshamurthy ${ }^{1}$, V. Ravindra ${ }^{1}$, P. Panneerselvam ${ }^{1}$, K. Sathyarahini ${ }^{1} \&$ R. M. Bhat ${ }^{1}$ \\ ${ }^{1}$ Indian Institute of Horticultural Research, Hessaraghatta Lake Post, Bengaluru, India \\ Correspondence: A. N. Ganeshamurthy, Division of Soil Science, Indian Institute of Horticultural Research, \\ Hessaraghatta Lake Post, Bengaluru 560089, India. Tel: 91-944-981-6282. Fax: 91-802-844-6649. E-mail: \\ angmurthy@gmail.com
}

Received: February 13, 2016 Accepted: May 23, 2016 Online Published: June 15, 2016

doi:10.5539/jas.v8n7p173 URL: http://dx.doi.org/10.5539/jas.v8n7p173

\begin{abstract}
Conservation horticulture is a new concept in management of soil health under perennial horticultural cropping systems. Experiments conducted reasonably over a long period on such soil management systems provide valuable information about sustainability of production systems. This paper reports the results of comprehensive investigations on soil chemical, physical, biochemical and biological properties of soils under conventional and conservation horticulture practices over a long period in drylnd mango orchards on Alfisols. Effects of conservation tillage, inter cropping and cover cropping on soil carbon fractions was measured by determination of loss on ignition, organic carbon (OC) and active carbon (AC). Soil biochemical properties were evaluated by measuring glomalin and extracellular enzymatic activities viz., dehydrogenase, urease, phosphomonoestrase and arylsulphatase and measurement of soil microbial biomass carbon (MBC) and carbon mineralization. Biological status was evaluated by estimating bacterial, actinobacterial and fungal populations, earthworms, micro arthropods and centipedes. Soil physical status was assessed by measuring bulk density, soil moisture status and infiltration rates.

Conservation horticultural practices improved the quality of soil, especially near the surface, by lowering the bulk density and enhancing infiltration rate. The soil aggregate formation and water stability have enhanced in plots with conservation practices because of higher production of glomalin compared with vegetable and orchard plots where conventional practices were followed. Relationship between measured infiltration and soil properties showed high average IRs in conservation plots due to high organic matter content, low bulk density values and enhanced exchangeable basic cations. Vegetable plots and conventional mango plots showed complete decline in earthworm and centipede population while plots with conservation practices showed a build-up of their population. Microbial and biochemical properties significantly improved in plots with conservation horticultural practices over orchard plots with conventional practices. Legumes as inter and cover crops were found to be superior in improving soil quality than sweet potato.
\end{abstract}

Keywords: active carbon, conservation horticulture, mango, extracellular enzymes, glomalin, soil aggregates

\section{Introduction}

The productivity of tropical orchards is declining due to deterioration in soil health. To enhance factor productivity and increase fruit yields improvement of orchard soil health is a must. Conservation horticulture attaches great significance to improving soil health through improving soil structure and biodiversity. Soil carbon lost during tillage can be accrued through conservation practices viz., zero tillage, inter and cover crops, moisture conservation etc. (Conant et al., 2007). Enhanced biological activity as a consequence of enhanced soil organic matter is directly responsible for improvement of soil structure, nutrient storage and reduced pests and diseases. Changes that occur in total soil organic carbon (TOC) resulting from changes in soil management are slow and often difficult to measure. There is need to have an early indicator for understanding the management effects on soil health. The early indications of improvement in soil health properties following changes in management practices are provided by such properties of soil like relatively labile fractions of soil carbon that 
are easily available to soil microorganisms. To distinguish from the general $\mathrm{C}$ pool that is only very slowly altered by microbial activities, a labile fraction of soil $\mathrm{C}$ called the active $\mathrm{C}$ (AC) pool are estimated for better understanding of the soil changes following changes in management. This pool is very closely related with the microbial activity in the soil and is very sensitive to any changes in soil management. Fractions of soil organic carbon that represent active $\mathrm{C}$ include microbial biomass $\mathrm{C}$ (MBC), particulate organic matter and sugars. Extra cellular free soil enzymes and other microbial related soil properties like the changes in the activity of microbial populations and $\mathrm{MBC}$ are used to predict the effect of farm management on soil biological status and improvement in soil quality (Melero et al., 2007; Ganeshamurthy, 2009; Hazarika et al., 2013).

We assessed the effects of conservation horticultural practices on soil physical, chemical, biological and biochemical properties in mango orchards under four distinct management situations in semiarid tropical regions on Alfisols. We considered these parameters as reliable indicators of change in soil with a long history of conservation horticultural practices. Our hypothesis was that conservation horticultural practices will have a positive effect on soil quality by improving soil biodiversity, soil organic $\mathrm{C}$ sequestration, biochemical properties and as a consequence the soil physical properties.

\section{Materials and Methods}

\subsection{Location}

The experimental sites are situated in the South-Deccan plateau in peninsular India to the South-Eastern corner of Karnataka State at the main research farm of the Indian Institute of Horticultural Research, Hessaraghatta, Bengaluru at an elevation of about 900 meters above sea level. It spreads between the latitudinal parallels of $12^{\circ} 39^{\prime} \mathrm{N}$ and $13^{\circ} 18^{\prime} \mathrm{N}$, longitudinal meridians of $77^{\circ} 22^{\prime} \mathrm{E}$ and $77^{\circ} 52^{\prime} \mathrm{E}$. The region has four narrowly demarcated seasons like The dry season with clear bright weather is from December to February with summer from March to May, followed by the southwest monsoon season from June to September while October and November constitute the northeast monsoons or retreating southwest monsoon season and in climatological terms defined as "seasonally dry tropical savanna climate with four seasons". The main features of the climate of this region are the agreeable range of temperatures, from the highest mean maximum of $33{ }^{\circ} \mathrm{C}$ in April to the lowest mean minimum of $14{ }^{\circ} \mathrm{C}$ in January. The two rainy seasons, the southwest and northeast monsoons follow one after the other but with opposite wind regimes from June to September and October to November,

\subsection{Selection of Orchards}

Thirty years old alphonso mango gardens grafted on common rootstocks under different managements were selected for assessing the benefits of conservation practices, viz.,

$>$ Mango orchards under clean cultivation and intensive management (CCIM);

$>$ Mango orchards under weed cover but under intensive management (WCIM);

$>$ Mango orchards under WCIM put under conservation practices since six years (CHP).

For relative quantification of effects of conservation practices a field crop plot continuously under vegetable cultivation was also selected for comparison and was designated as clean cultivation vegetable field (CCVF).

\subsection{The Soil}

All these four systems were located within a single block on a fairly levelled 1 and covering an area of about 10 ha. The soil of the study site is an Alfisol.

\subsection{Orchard Management}

Mango cultivar Alphonso was planted in 1984 accommodating 160 trees per hectare. These trees received fertilizers as per details given in Table 1. Standard practices as recommended by IIHR, Bengaluru were followed with respect to orchard management including pest and disease management except that the floor management was different as described below: 
Table 1. Residue and fertilizers $\left(\mathrm{kg} \mathrm{ha}^{-1}\right)$ added per year to the system

\begin{tabular}{lllllll}
\hline Organic residues/Fertilizers & CCVF & CCIM & WCIM & CHPM & CHSP & CHPC \\
\hline Organic residues & - & & & & & \\
Plant residues & 2000 & 4000 & 25000 & 20000 & 15000 \\
Organic manures(FYM) & 10000 & 8000 & 8000 & - & - & - \\
Total & 10000 & 10000 & 12000 & 25000 & 20000 & 15000 \\
\hdashline Fertilizers & & 158 & 158 & 158 & 158 & 158 \\
$\mathrm{~N}$ & & 158 & 158 & 158 & 158 & 158 \\
$\mathrm{P}_{2} \mathrm{O}_{5}$ & & 237 & 237 & 237 & 237 & 237 \\
$\mathrm{~K}_{2} \mathrm{O}$ & - & - & - & - & - & - \\
$\mathrm{Ca}$ & - & - & - & - & - & - \\
$\mathrm{Mg}$ & 20 & 5 & 5 & 2 & 2 & 2 \\
$\mathrm{~S}$ & 5 & - & - & - & - & - \\
$\mathrm{Zn}$ & - & - & - & - & - & - \\
$\mathrm{Fe}$ & 1 & - & - & - & - & - \\
$\mathrm{Cu}$ & - & - & - & - & - & - \\
$\mathrm{Mn}$ & - & - & - & - & - & - \\
$\mathrm{B}$ & - & & & - & - \\
\hline
\end{tabular}

Note. CCIM: Mango orchards under clean cultivation and intensive management: This orchard floor was kept weed free throughout the year by ploughing regularly beginning with the onset of monsoon rains in June every year. The frequency of ploughing depended upon weed growth and varied from three to four ploughing every year.

WCIM: Mango orchards under weed cover but under intensive management: This orchard floor was not weeded and allowed for natural weed growth. But the floor was cultivated only after monsoon rains ceased and weeds were incorporated in the soil.

CHP: Since last six years part of the WCIM orchard was shifted to conservation horticulture management practices like zero cultivation, legume cover crop Mucuna prurience and inter cropping with sweet potato and cow peas. The treatments were designated as CHPM (Mucuna pruriense), CHPC (Cow peas) and CHPSP (Sweet potato).

CCVF: For relative quantification of effects of conservation practices, an adjacent field crop plot continuously under vegetable cultivation was also selected for studies and it is designated as clean cultivation vegetable field (CCVF). This field was under regular ploughing and annually two vegetables were grown like tomato, okra, French bean, cabbage etc. and received regular application of both fertilizers and organic manures. Practices as recommended by IIHR, Bengaluru were followed with respect to vegetable crop management including pests and diseases.

The annual manure and fertilizing in these plots in the past six years is given in Table 1.

\subsection{Sampling}

At the end of six years of conservation practices, soil samples were collected from $0-15 \mathrm{~cm}$ during the onset of monsoon in the month of June. Twelve soil cores of each individual subplot were taken and pooled. The moist field soil was sieved $(2 \mathrm{~mm})$ and washed, homogenised \& subdivided in to two subsamples. One of them was immediately stored at $4{ }^{\circ} \mathrm{C}$ for microbiological and enzymatic activities and the other was air-dried for chemical analysis.

\subsection{Soil Physical Properties}

\subsubsection{Soil Bulk Density and Gravimetric Water Content}

During the onset of monsoon soil bulk density was determined at four depths viz., 0-5, 5-10, 10-15, and 15-30 $\mathrm{cm}$. by the cylindrical and weighing methods (Dospechov et al., 1977). Soil samples were taken at 4 places per each treatment plot and the cylinder size used was $200 \mathrm{~cm}^{3}$. 


\subsubsection{Profile Soil Moisture}

At the end of monsoon season profile samples were drawn at $30 \mathrm{~cm}$ interval up to $150 \mathrm{~cm}$. randomly from 4 places per each treatment plot. They were immediately transferred to pre weighed boxes and moisture content was determined gravimetrically.

\subsubsection{Field Infiltration Measurement}

Field infiltration test at two points on each experimental plot was conducted using double ring infiltrometer as described by Bouwer (1986). The inner ring $(30 \mathrm{~cm}$ in diameter) was positioned at the centre of the outer ring (50 $\mathrm{cm}$ diameter). The two rings were driven down uniformly with a hammer to a depth of $15 \mathrm{~cm}$. Some pieces of dried grasses were laid within the rings to prevent surface disturbance. Both rings were filled with water simultaneously. The outer ring acted as a buffer to prevent lateral flow of water from the inner ring, while vertical flow of water into the profile was achieved. Measurement of infiltrated water was recorded until steady state.

\subsubsection{Soil Aggregates}

Aggregate composition of the investigated samples $(0-15 \mathrm{~cm}$. depth) was determined by dry sieving and water stability of the aggregates by wet sieving following Savinov (Gajic, 2005). Both by dry and wet sieving two structural aggregate sizes viz., $<3 \mathrm{~mm}$ and $>3 \mathrm{~mm}$ were separated.

\subsubsection{Soil Carbon}

Loss on ignition (LOI): For soil C estimation a small portion of 25 -g subsamples were finely ground $(<250 \mu \mathrm{m})$. By using an Elementor carbon analyser the carbon was estimated by dry combustion method (Nelson \& Sommers, 1982). Since all soil samples were acidic the estimated total $\mathrm{C}$ was considered equivalent to organic $\mathrm{C}$.

\subsubsection{Oxidisable Organic Carbon (OC)}

Air dried soil samples were analyzed for oxidisable organic carbon by wet oxidation method (Walkley \& Black, 1934).

\subsubsection{Active Carbon Estimation (AC)}

Dilute $(0.02 \mathrm{M})$ solution of slightly alkaline $\mathrm{KMnO}_{4}$ was used as extractant for estimation of active carbon following Weil et al. (2003).

\subsubsection{Soil Microbial Biomass C (SMBC) and Carbon Mineralization (CMIN)}

SMBC and CMIN were determined in duplicate subsamples (Franzluebbers et al., 1995). For C mineralization determination, subsamples of soils were moistened and incubated at $25 \pm 1{ }^{\circ} \mathrm{C}$ in $1-\mathrm{L}$ air tight containers with 10 $\mathrm{mL}$ of $1.0 \mathrm{~mol} \mathrm{~L}^{-1} \mathrm{NaOH}$ in a vial to absorb $\mathrm{CO}_{2}$. These traps were replaced at 3 and $10 \mathrm{~d}$, and removed at $24 \mathrm{~d}$. Evolved $\mathrm{CO}_{2}$ was determined by titration of alkali with $1.0 \mathrm{~mol} \mathrm{~L}^{-1} \mathrm{HCl}$. To estimate microbial biomass carbon, a subsample was removed at $10^{\text {th }}$ day, fumigated with chloroform, and incubated separately for another 10 days. The flush of $\mathrm{CO}_{2}$ from this represents microbial biomass $\mathrm{C}$ (Voroney \& Paul, 1984) and calculated using the equation:

$$
\mathrm{SMBC}=\left(\mathrm{mg} \mathrm{CO} \mathrm{CO}_{2}-\mathrm{C} \mathrm{kg}^{-1} \text { soil }\right) \text { fumigated/kc, where, } \mathrm{kc}=0.41
$$

\subsubsection{Soil Chemical Properties}

Soil $\mathrm{pH}$ and EC were measured in a soil: suspension ratio of 1:2 using an Elico combined pH-EC meter. Another part of the soil sample was passed through a $2 \mathrm{~mm}$ sieve and used for analysis of soil available nutrients like $\mathrm{N}$ (Alkaline $\mathrm{KMnO}_{4}$ method, Subbaiah \& Asija, 1956), P (0.025 M HCl-0.03 M NH${ }_{4} \mathrm{~F}, \mathrm{pH} 2.6$, Bray \& Kurtz, 1945), $\mathrm{K}\left(1 \mathrm{~N} \mathrm{NH}_{4} \mathrm{OAc}\right.$ extractable $\mathrm{K}, \mathrm{pH} 7.0$, Hanway \& Heidel, 1952) and $\mathrm{S}\left(0.01 \mathrm{M} \mathrm{CaCl}_{2}\right.$ extractable). DTPA extractable- $\mathrm{Zn}, \mathrm{Cu}, \mathrm{Fe}$ and $\mathrm{Mn}$ was estimated by using Atomic Absorption Spectrometer (model Perkinelmer 402), whereas available boron was estimated by hot water soluble method (Jackson, 1973).

\subsubsection{Soil Biological and Biochemical Properties}

Microbial population: Bacteria, actionbacteria, fungus, PSB, azatobacter and total microbial population and dehydrogenase, phosphomonoestrase, arylsulphatase activities were determined according to Alef and Nannipieri (1995).

Macrofauna abundance: This study was conducted from the mid monsoon of 2014. Monolith samples of $20 \times 20$ $\times 20 \mathrm{~cm}$. were taken to determine densities of earthworms, micro arthropods and centipedes in all the fields. Three monolith samples were taken within each plot. The monolith samples were collected within a period of 5 days of heavy $10 \mathrm{~mm}$ rain. The earthworms, micro arthropods and centipedes in the upper $20 \mathrm{~cm}$ of the soil were 
collected by hand sorting. The earthworms below $20 \mathrm{~cm}$ depth were extracted using formaldehyde solution $(0.185 \%)$. Formaldehyde solution was poured into the hole left by the monolith. The hole was monitored for 20 minutes for earthworms coming to the surface. The monolith samples were hand sorted in the field.

\subsection{Statistical Analysis}

Statistical analyses were carried out using SPSS 11.0 for Windows and the results were expressed as mean values. Significant differences between management systems were shown by a Student's t-test at $p<0.05$. The data set of soil chemical and biochemical variables was also analysed using discriminant analysis.

\section{Results}

\subsection{Soil Physical Properties}

\subsubsection{Soil Bulk Density}

The effect of conservation practices like minimum tillage, inter crops and residue management on soil bulk density is conspicuous and mainly confined to the surface part and plough layer. Surface part $(0-5 \mathrm{~cm})$ generally had lower BD than plough layer (Table 2). Vegetable field had higher BD $\left(1.32 \mathrm{Mg} / \mathrm{m}^{-3}\right)$ than mango orchard soils. Clean cultivation in mango orchards had resulted in higher BD $\left(1.30 \mathrm{Mg} / \mathrm{m}^{-3}\right)$ than weed infested plots. Weed infested plots had higher BD than all other intercrops and cover crop plots. Cowpeas plots had lower BD $\left(1.07 \mathrm{Mg} / \mathrm{m}^{-3}\right)$ than sweet potato plots $\left(1.16 \mathrm{Mg} / \mathrm{m}^{-3}\right)$ but higher than Mucuna plots $\left(1.03 \mathrm{Mg} / \mathrm{m}^{-3}\right)$. This trend was observed even at $15-30 \mathrm{~cm}$. depth of the soil.

Table 2. Soil bulk density under different conservation practices measured during sixth year of experimentation

\begin{tabular}{lllllll}
\hline & \multicolumn{5}{c}{ Soil bulk density $\left(\mathrm{Mg} / \mathrm{m}^{-3}\right)$} \\
\cline { 2 - 7 } Soil depth $(\mathrm{cm})$ & CCVF & CCIM & WCIM & \multicolumn{3}{c}{ CHP } \\
\cline { 5 - 7 } & & & & CHPM (Mucuna) & CHPSP (Sweet potato) & CHPC (Cow peas) \\
\hline $0-5$ & $1.32 \mathrm{a}$ & $1.30 \mathrm{a}$ & $1.19 \mathrm{~b}$ & $1.03 \mathrm{c}$ & $1.16 \mathrm{~b}$ & $1.07 \mathrm{c}$ \\
$5-10$ & $1.47 \mathrm{a}$ & $1.38 \mathrm{~b}$ & $1.29 \mathrm{c}$ & $1.17 \mathrm{~d}$ & $1.22 \mathrm{c}$ & $1.17 \mathrm{~d}$ \\
$10-15$ & $1.52 \mathrm{a}$ & $1.49 \mathrm{a}$ & $1.48 \mathrm{a}$ & $1.39 \mathrm{~b}$ & $1.44 \mathrm{a}$ & $1.38 \mathrm{~b}$ \\
$15-30$ & $1.53 \mathrm{a}$ & $1.51 \mathrm{a}$ & $1.50 \mathrm{a}$ & $1.50 \mathrm{a}$ & $1.51 \mathrm{a}$ & $1.50 \mathrm{a}$ \\
\hline
\end{tabular}

Note. *: Letters following similar alphabets within a row are non-significant.

\subsubsection{Profile Soil Moisture}

Both the crops and conservation practices had significant influence on the post-harvest soil profile moisture storage. Vegetable system exhausted the soil water more than fruit orchards (Table 3). Conservation practices like inter and cover crops with zero tillage has conserved soil moisture more than other orchard plots with clean cultivation practices and weed infestation. The effect was more conspicuous in the upper layers than in the lower layers. The total profile storage (Table 3) in the beginning of the season was $53.58 \mathrm{~mm} / 150 \mathrm{~cm}$ which remained at 35.86 in vegetable crops field and $41.32 \mathrm{~mm} / 150 \mathrm{~cm}$. in intensive mango field (CCIM). The legume cover crop Mucuna was found conserving more soil moisture than other intercrops. The profile storage in Mucuna cover crop field (CHPM) was 46.66 and in cow pea cover crop plot (CHPC) was $46.10 \mathrm{~mm} / 150 \mathrm{~cm}$. Among intercrops sweet potato was more exhaustive than cowpeas, but was more efficient in conserving soil moisture than clean cultivation or orchard with weed infestation. The profile storage in sweet potato plot (CHSP) was 45.32. Soil moisture content at lower depths was higher in all conservation plots than in vegetable (CCVF) system or orchards under clean cultivation (CCIM) and weed infestation (WCIM). 
Table 3. Initial and post-harvest Soil profile moisture under different conservation practices measured during sixth year of experimentation

\begin{tabular}{|c|c|c|c|c|c|c|c|}
\hline \multirow{3}{*}{ Soil depth $(\mathrm{cm})$} & \multirow{3}{*}{ Initial soil moisture } & \multicolumn{6}{|c|}{ Soil moisture after cropping (Volumetric water content, $\mathrm{cm} / \mathrm{cm}$ ) } \\
\hline & & \multirow[b]{2}{*}{$\mathrm{CCVF}$} & \multirow[b]{2}{*}{ CCIM } & \multirow[b]{2}{*}{ WCIM } & \multicolumn{3}{|c|}{ CHP } \\
\hline & & & & & $\begin{array}{l}\text { CHPM } \\
\text { (Mucuna) }\end{array}$ & $\begin{array}{l}\text { CHPSP } \\
\text { (Sweet potato) }\end{array}$ & $\begin{array}{l}\text { CHPC } \\
\text { (Cow peas) }\end{array}$ \\
\hline $0-30$ & 0.212 & 0.142 & 0.170 & 0.171 & 0.184 & 0.176 & 0.180 \\
\hline $30-60$ & 0.235 & 0.143 & 0.179 & 0.176 & 0.190 & 0.182 & 0.188 \\
\hline $60-90$ & 0.261 & 0.150 & 0.188 & 0.211 & 0.209 & 0.200 & 0.209 \\
\hline $90-120$ & 0.254 & 0.176 & 0.227 & 0.241 & 0.243 & 0.240 & 0.243 \\
\hline $120-150$ & 0.209 & 0.174 & 0.211 & 0.204 & 0.216 & 0.210 & 0.216 \\
\hline $\begin{array}{l}\text { Profile storage } \\
(\mathrm{mm} / 150 \mathrm{~cm})\end{array}$ & $53.58^{*}$ & 35.86 & 41.32 & 43.09 & 46.66 & 45.32 & 46.10 \\
\hline
\end{tabular}

Note. $*=\%$ moisture on dry weight basis $\times \mathrm{BD} \times$ Thickness of soil layer/100.

\subsubsection{Infiltration Rate}

The steady infiltration rates (IRs) measured using double ring infiltrometer is presentedin Figure 1. The mean steady IRs were very low $(136 \mathrm{~mm} / \mathrm{h})$ for vegetable plot (CCVF) and mango orchards $(180 \mathrm{~mm} / \mathrm{h})$ under clean cultivation (CCIM). Among orchard plots with ground cover, the plot with weed infestation had the lowest steady state flow of $336 \mathrm{~mm} / \mathrm{h}$. Plots with cover crop \& with cowpea as intercrop had similar steady state flow (360 and $354 \mathrm{~mm} / \mathrm{h}$, respectively) while intercrop with sweet potato recorded lower steady state flow $(344 \mathrm{~mm} / \mathrm{h}$ ) over other conservation plots. The analysis of variance which was done using the steady state IRs showed significant difference $(\mathrm{p}=0.05)$ among the treatment means indicating that the steady infiltration rates vary with the different conservation practices.

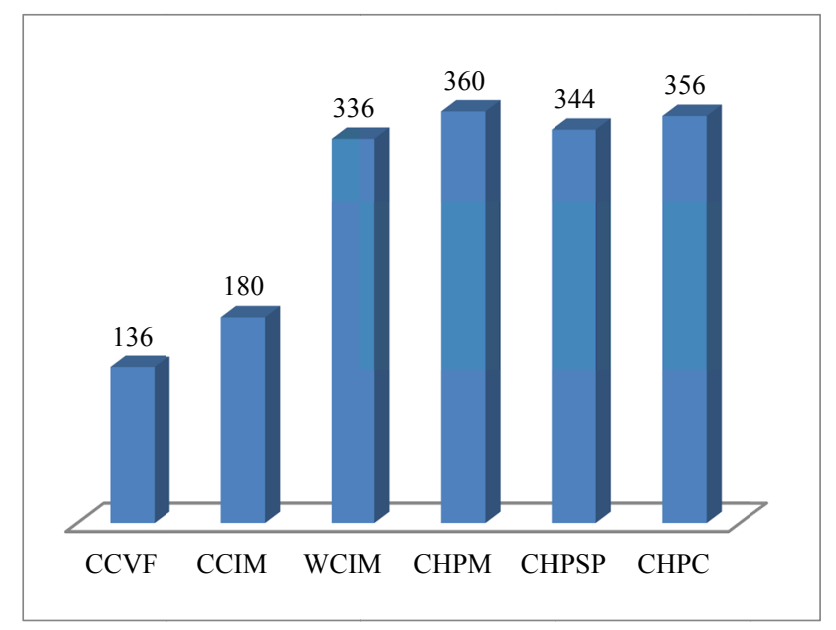

Figure 1. Steady state infiltration rate in different treatment plots

The graph of measured IRs against time (Figure 2) showed that IRs were at their highest values at the beginning of the experiment, but decreased steadily at different rates.

The steady state rate, irrespective of the treatments, attained between 105 to 120 minutes (1.75 to $2.0 \mathrm{hrs}$ ). Figure 3 represents the graphs of accumulated infiltration against time plotted for different treatments. The slopes of these graphs are the extrapolated values of infiltration rates and were in the order of CHPM $=$ CHPC (59.6) > CHPSP (56.6) > WCIM (53.4) > CCIM (31.5 > CCVF (27.9). 


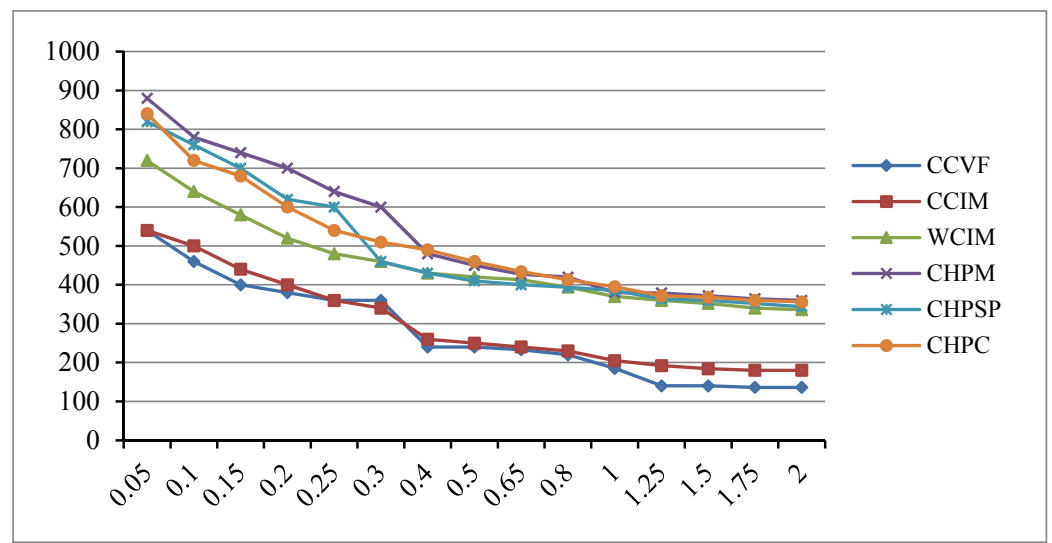

Figure 2. Infiltration rates in different conservation plots against time

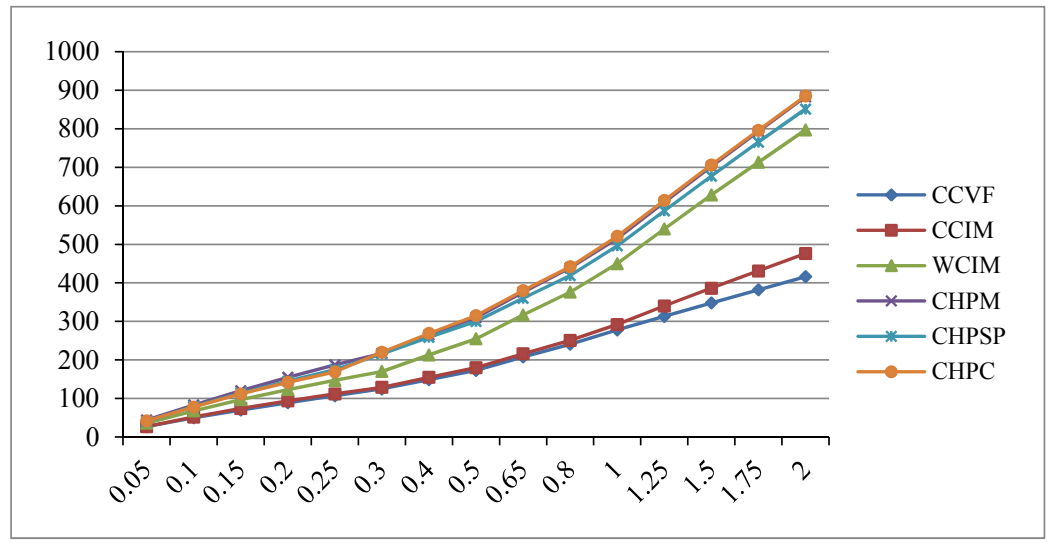

Figure 3. Accumulated infiltration against time

\subsubsection{Soil Aggregate Stability}

The influence of conservation practices on the soil physical properties of the arable layer is expressed practically through stability of the soil structure during the vegetation and hence an improvement of soil porosity determining drainage, aeration and plant available water capacity. Both these imply improvement of soil quality and productive capacity. The effect of conservation practices was more pronounced in macro aggregates than micro aggregates (Table 4$)$. The dry aggregates in the class $>3 \mathrm{~mm}$ was lowest $(59 \%)$ in vegetable plots (CCVF) followed by mango field (66\%) under intensive management (CCIM). The water stable aggregates also followed same trend with $40 \%$ in CCVF followed by mango field (44\%) under intensive management (CCIM) against $57 \%$ in CHPM. All plots with conservation practices had higher dry macro aggregates and water stable macro aggregates than intensive cultivation plots. Intercrop with cowpea and cover crop with Mucuna had the highest macro aggregates of $84 \%$ in both the plots followed by intercrop with sweet potato ( 75 and $49 \%$, respectively). Weed infested mango plot (WCIM) also had better macro aggregates (78 and 51\%, respectively) over CCVF and CCIM. 
Table 4. Aggregate distribution in different conservation plots

\begin{tabular}{|c|c|c|c|c|c|c|c|c|}
\hline \multirow[b]{2}{*}{ System } & \multicolumn{4}{|c|}{ Dry aggregates } & \multicolumn{4}{|c|}{ Wet aggregates } \\
\hline & $\begin{array}{l}>3 \mathrm{~mm} \\
\text { (\% by volume) }\end{array}$ & $\begin{array}{l}\text { Glomalin } \\
\left(\mathrm{mg} \mathrm{g}^{-1} \text { soil) }\right.\end{array}$ & $\begin{array}{l}<3 \mathrm{~mm} \\
\text { (\% by volume) }\end{array}$ & $\begin{array}{l}\text { Glomalin } \\
\left(\mathrm{mg} \mathrm{g}^{-1} \text { soil) }\right.\end{array}$ & $\begin{array}{l}>3 \mathrm{~mm} \\
\text { (\% by volume) }\end{array}$ & $\begin{array}{l}\text { Glomalin } \\
\left(\mathrm{mg} \mathrm{g}^{-1} \text { soil) }\right.\end{array}$ & $\begin{array}{l}<3 \mathrm{~mm} \\
\text { (\% by volume) }\end{array}$ & $\begin{array}{l}\text { Glomalin } \\
\left(\mathrm{mg} \mathrm{g}^{-1} \text { soil }\right)\end{array}$ \\
\hline CCVF & $59 a$ & $5.20 \mathrm{a}$ & $29 a$ & $5.04 \mathrm{a}$ & $40 \mathrm{a}$ & $4.85 \mathrm{a}$ & $53 a$ & $4.27 \mathrm{a}$ \\
\hline CCIM & $66 a$ & $5.78 \mathrm{~b}$ & $29 a$ & $5.59 \mathrm{~b}$ & $44 b$ & $5.04 \mathrm{a}$ & $50 \mathrm{a}$ & $4.83 b$ \\
\hline WCIM & $78 b$ & $5.95 b$ & $33 b$ & $5.63 \mathrm{c}$ & $51 \mathrm{c}$ & $5.26 \mathrm{~b}$ & $23 b$ & $5.04 \mathrm{c}$ \\
\hline CHPM & $84 c$ & $6.51 \mathrm{c}$ & $40 \mathrm{c}$ & $6.22 \mathrm{c}$ & $57 \mathrm{~d}$ & $6.11 \mathrm{c}$ & $16 \mathrm{c}$ & $5.82 \mathrm{~d}$ \\
\hline CHSP & $75 b$ & $5.44 b$ & $39 \mathrm{c}$ & $5.17 \mathrm{~b}$ & $49 c$ & $5.11 \mathrm{~b}$ & $31 b$ & $5.04 \mathrm{c}$ \\
\hline CHPC & $84 c$ & $6.17 \mathrm{c}$ & $38 \mathrm{c}$ & $5.93 \mathrm{c}$ & $54 \mathrm{c}$ & $5.82 \mathrm{c}$ & $18 \mathrm{c}$ & $5.50 \mathrm{~d}$ \\
\hline
\end{tabular}

Note. *: Letters following similar alphabets within a row are non-significant.

\subsection{Soil Organic Carbon}

\subsubsection{LOI and OC}

The loss on ignition \& OC were higher in plots with conservation horticulture practices as compared with plots following conventional practices. CCVF had 9.86 and $5.16 \mathrm{~g} \mathrm{~kg}^{-1} \mathrm{LOI}$ and $\mathrm{OC}$ as against 12.34 and $6.64 \mathrm{~g} \mathrm{~kg}^{-1}$, respectively, in CHPC (Table 5). CCIM also recorded lower values of LOI and OC. Inter and cover crops in mango orchard recorded higher LOI and OC than weed infested mango plots (11.03 and $\left.6.02 \mathrm{~g} \mathrm{~kg}^{-1}\right)$.

\subsubsection{AC, SMBC and CMIN}

These are forms of soil carbon which are small in quantity but are very dynamic and susceptible to management effects. CCVF recorded the lowest AC (18.06), SMBC (128) and CMIN (10.68). This was followed by CCIM (Table 5). Ground cover of orchards helped in build-up of carbon in soil. Legumes were more efficient than weeds or vegetables in enhancing the C content of the soil. Highest AC (37.7), SMIC (199) and CMIC (18.71) was recorded in mango plots under Mucuna cover crop (CHPM).

Table 5. Soil organic carbon fractions in different conservation plots

\begin{tabular}{llllllll}
\hline Soil properties & CCVF & CCIM & WCIM & CHPM & CHSP & CHPC & LSD (0.05) \\
\hline Loss on ignition $(\mathrm{LOI}),\left(\mathrm{g} \mathrm{kg}^{-1}\right)$ & 9.86 & 10.98 & 11.03 & 11.85 & 11.27 & 12.34 & 0.96 \\
Organic C (OC), $\left(\mathrm{g} \mathrm{kg}^{-1}\right)$ & 5.16 & 5.78 & 6.02 & 6.32 & 5.98 & 6.64 & 0.51 \\
Active C (AC), $\left(\mathrm{mg} \mathrm{kg}^{-1}\right)$ & 18.06 & 20.23 & 29.07 & 37.7 & 26.82 & 35.24 & 2.37 \\
Soil microbial biomass C (SMBC), $\left(\mathrm{mg} \mathrm{kg}^{-1}\right)$ & 128 & 151 & 166 & 199 & 174 & 192 & 11.44 \\
C mineralization $(\mathrm{CMIN}),(\mathrm{mg} / \mathrm{kg}$ of soil/day) & 10.68 & 11.53 & 13.02 & 18.71 & 13.56 & 16.32 & 0.73 \\
\hline
\end{tabular}

\subsubsection{Soil Chemical Properties}

Conservation practices in mango orchards significantly altered some of the basic soil chemical properties like $\mathrm{pH}$, exchangeable bases and exchangeable nutrient cations. The soil EC and exchangeable $\mathrm{Na}$ did not show any significant change (Table 6). Continuous vegetable cultivation or a clean cultivation in mango orchard led to acidification of soil by recording the lowest $\mathrm{pH}$ values $(\mathrm{CCVF}=5.84$ and $\mathrm{CCIM}=5.89)$. All other plots having ground cover with crops or weeds recorded higher $\mathrm{pH}$. Legume inter crop $(\mathrm{CHPC}=6.01)$ and cover crop $(\mathrm{CHPM}=6.18)$ recorded the highest soil $\mathrm{pH}$. This was also expressed in terms of exchangeable bases including exchangeable $\mathrm{Ca}$ and $\mathrm{Mg}$. Highest exchangeable base was recorded in CHPM (96\%) followed by CHPC (91\%) and the lowest in CCVF (79). 
Table 6. Some soil chemical properties in different conservation plots

\begin{tabular}{llllllll}
\hline Soil properties & CCVF & CCIM & WCIM & CHPM & CHSP & CHPC & LSD $(0.05)$ \\
\hline $\mathrm{pH}$ & 5.84 & 5.89 & 5.98 & 6.18 & 5.95 & 6.01 & 0.06 \\
$\mathrm{E.C}$ & 0.182 & 0.164 & 0.169 & 0.176 & 0.161 & 0.177 & $\mathrm{NS}$ \\
$\mathrm{Ca}^{*}$ & 4.6 & 4.8 & 5.0 & 5.4 & 5.0 & 5.4 & 0.07 \\
$\mathrm{Mg}^{*}$ & 1.9 & 1.7 & 1.9 & 2.1 & 1.9 & 2.1 & 0.13 \\
$\mathrm{Na}^{*}$ & $\operatorname{tr}$ & $\operatorname{tr}$ & $\operatorname{tr}$ & $\operatorname{tr}$ & $\operatorname{tr}$ & $\operatorname{tr}$ & - \\
$\mathrm{K}^{*}$ & 0.22 & 0.24 & 0.27 & 0.32 & 0.29 & 0.31 & 0.04 \\
Exchangeable bases, \% & 79 & 82 & 88 & 96 & 88 & 91 & 2.11 \\
CEC $^{*}$ & 7.7 & 7.7 & 8.0 & 8.6 & 7.9 & 8.6 & 0.16 \\
\hline
\end{tabular}

Note. ${ }^{*} \mathrm{cmol}(\mathrm{p}+) \mathrm{kg}^{-1} ; \mathrm{tr}=$ trace.

\subsubsection{Available Nutrients in Soil}

The soil available nutrients status changed significantly under different treatments (Table 7). The changes are in proportion to the levels of nutrients added to these plots over time. Vegetable field received significantly higher amounts of fertilizers than other plots (Table 1). Hence the residual level of all fertilizer elements was higher in CCVF compared to other plots. CCIM recorded the lower values of available nutrients whereas in all other mango plots the levels were above this plot. Vegetable plots received $\mathrm{Mg}$ and $\mathrm{S}$ application and hence recorded higher values of $\mathrm{Mg}$ and $\mathrm{S}$ over other plots. All micronutrient levels were improved under conservation horticultural plots compared with CCIM although these levels were higher in vegetable plot due to their external addition.

Table 7. Available nutrients in soil in different conservation plots

\begin{tabular}{llllllll}
\hline Available nutrients & CCVF & CCIM & WCIM & CHPM & CHSP & CHPC & LSD (0.05) \\
\hline $\mathrm{N}, \mathrm{kg} \mathrm{ha}^{-1}$ & 146 & 126 & 151 & 207 & 155 & 182 & 23 \\
$\mathrm{P}_{\mathrm{kg} \mathrm{ha}}{ }^{-1}$ & 26 & 19 & 21 & 27 & 26 & 27 & 1.4 \\
$\mathrm{~K}, \mathrm{~kg} \mathrm{ha}^{-1}$ & 188 & 158 & 166 & 177 & 182 & 179 & 34 \\
$\mathrm{Ca}, \mathrm{kg} \mathrm{ha}^{-1}$ & 2040 & 2120 & 2010 & 2370 & 2208 & 2364 & 107 \\
$\mathrm{Mg}, \mathrm{kg} \mathrm{ha}^{-1}$ & 482 & 434 & 485 & 496 & 485 & 490 & 39 \\
$\mathrm{~S}, \mathrm{~kg} \mathrm{ha}^{-1}$ & 16.4 & 11.6 & 12.5 & 14.3 & 12.1 & 14.0 & 1.16 \\
$\mathrm{Zn}, \mathrm{kg} \mathrm{ha}^{-1}$ & 1.28 & 1.19 & 1.19 & 1.26 & 1.06 & 1.02 & 0.04 \\
$\mathrm{Cu}, \mathrm{kg} \mathrm{ha}^{-1}$ & 3.44 & 2.12 & 2.02 & 2.10 & 2.27 & 2.22 & 0.26 \\
$\mathrm{Fe} . \mathrm{kg} \mathrm{ha}^{-1}$ & 31.65 & 24.29 & 27.20 & 27.36 & 27.44 & 27.52 & 2.63 \\
$\mathrm{Mn}, \mathrm{kg} \mathrm{ha}^{-1}$ & 48.08 & 43.21 & 44.17 & 45.11 & 45.23 & 44.80 & 2.08 \\
$\mathrm{~B} . \mathrm{kg} \mathrm{ha}^{-1}$ & 0.81 & 0.68 & 0.70 & 0.73 & 0.70 & 0.73 & 0.06 \\
\hline
\end{tabular}

\subsubsection{Soil Microbial and Biochemical Properties}

Conservation horticulture practices had significantly influenced the microbial diversity and population in the soil. Clean cultivation either in mango orchard or in open vegetable field resulted in a drastic reduction of fungal population compared to bacterial population (Table 8). There was a four-fold increase in population of PSB, three fold in actinobacteria and a twofold higher population of azatobacter in conservation plots over CCVF and CCIM. BY and large the conservation plots had three to four folds higher fungal population and two folds higher bacterial population over vegetable field (CCVF) or mango under clean cultivation (CCIM). The average density of both bacteria and fungi has followed the order: CCVF $<$ CCIM $<$ WCIM $<$ CHSP $<$ CHPC $<$ CHPM. 
Table 8. Soil microbial population in conventional and conservation plots

\begin{tabular}{llllllll}
\hline Microbial properties & CCVF & CCIM & WCIM & CHPM & CHSP & CHPC & LSD (0.05) \\
\hline Bacteria & 6.2 & 7.4 & 10.2 & 13.6 & 11.1 & 12.2 & 1.47 \\
Fungus & 4.6 & 6.6 & 10.6 & 18.7 & 13.7 & 16.1 & 1.16 \\
Bacteria/Fungus & 0.742 & 0.892 & 1.04 & 1.375 & 1.234 & 1.319 & - \\
PSB & 1.1 & 2.6 & 3.1 & 4.8 & 4.0 & 4.3 & 0.73 \\
ACT & 1.4 & 2.0 & 3.0 & 3.8 & 3.6 & 3.9 & 0.58 \\
AZO & 4.7 & 4.7 & 7.7 & 8.3 & 8.0 & 8.4 & 0.22 \\
Total & 18.0 & 23.3 & 34.6 & 49.2 & 40.4 & 44.9 & 3.64 \\
Soil respiration (mg/kg of soil/day) & 10.68 & 11.53 & 13.02 & 18.71 & 13.56 & 16.32 & 0.86 \\
\hline
\end{tabular}

From the ratio of bacteria to fungi (Figure 4) it can be inferred that conventional vegetable (CCVF) and mango plots(CCIM) was dominant with bacteria followed by WCIM, CHSP, CHPC and CHPM. Proportionately higher fungi in CHPM or CHPC than CCVF and CCIM have been revealed, indicating higher importance of fungi to decomposition of residues and nutrient mineralization in these systems. Among the crops, the ratio of bacteria to fungi was highest with Mucuna followed by cowpea and sweet potato (1.234).

Significantly higher levels of extracellular enzyme activities were recorded in all plots with conservation practices compared with plots following conventional practices like CCVF and CCIM. Dehydrogenase activity was recorded significantly lower by continuous cultivation of soil, in particular by intensive ploughing and bedding in CCVF (117 $\mu \mathrm{g} \mathrm{TPFg}^{-1}$ soil $\mathrm{h}^{-1}$ ) and CCIM (139). The other three hydrolysing enzymes, urease, phosphomonoesterase and arylsulphatase followed similar trend as shown in Table 9.

Table 9. Soil biochemical properties in conventional and conservation plots

\begin{tabular}{llllllll}
\hline Biochemical Properties & CCVF & CCIM & WCIM & CHPM & CHSP & CHPC & LSD (0.05) \\
\hline Dehydrogenase $\left(\mu \mathrm{g} \mathrm{TPFg}^{-1}\right.$ soil h$\left.^{-1}\right)$ & 117 & 139 & 320 & 414.04 & 238 & 401 & 19.6 \\
Urease $\left(\mu \mathrm{g}\right.$ urea $\mathrm{g}^{-1}$ soil $\left.\mathrm{hr}^{-1}\right)$ & 379 & 411 & 459 & 602 & 534 & 588 & 38 \\
Phosphomonoesterase $\left(\mu \mathrm{g}\right.$ p- nitrophenol hydrolyzed g $\left.\mathrm{soil} \mathrm{h}^{-1}\right)$ & 8.43 & 8.79 & 9.22 & 9.94 & 9.15 & 9.70 & 0.26 \\
Arylsulphatase $\left(\mu \mathrm{g} \mathrm{p}\right.$ - nitrophenol hydrolyzed $\left.\mathrm{g}^{-1} \mathrm{soil} \mathrm{h}^{-1}\right)$ & 6.18 & 7.63 & 8.34 & 8.66 & 8.02 & 8.45 & 0.22 \\
\hline
\end{tabular}

\subsubsection{Soil Faunal Activity}

Micro arthropods were the most predominant macro fauna group across all the plots (Table 10). There was a significantly higher macro fauna population in plots with conservation horticultural practices than plots with conventional practices. This was true for all the groups; i.e. earthworms, micro arthropods and centipedes. In the conservation horticultural systems, their abundance increased with amount of crop residues available. Earthworms and centipedes were absent in CCVF and CCIM plots indicating resource degradation in these plots and toxicity created by excessive use of agrochemicals.

Table 10. Soil faunal activity in conventional and conservation plots (no. $20 \mathrm{~cm}^{-3}$ )

\begin{tabular}{lllllll}
\hline Soil organisms & CCVF & CCIM & WCIM & CHPM & CHSP & CHPC \\
\hline Earthworms & 0 & 0 & 2 & 7 & 5 & 6 \\
Micro arthropods & 4 & 11 & 19 & 34 & 21 & 30 \\
Centipede abundance & 0 & 0 & 2 & 5 & 2 & 6 \\
\hline
\end{tabular}

\section{Discussion}

Gregorich et al. (1994) gave an operational definition of soil quality as 'The degree of fitness of a soil for a specific purpose'. Use of this definition hence depends upon the purpose for which the soil is destined (Singer \& Ewing, 2000). In orchard production systems soil quality improvement should be reflected in maintaining high 
productivity without significant soil or environmental degradation. In perennial horticulture systems while assessing the management system for sustainability we need to address such management systems that will not exhaust the resource base, imparts resilience to vulnerability and enhance or maintain productivity. Virtually the soil quality work is a translation of the concept of soil sustainability in terms of production and environmental protection. In soil quality evaluations we basically measure changes in physical, chemical and biological characteristics of the soil. Rapport (1995) defined a healthy soil as a stable system with high levels of biological diversity and activity, internal nutrient cycling, and resilience to disturbance. Changes in soil quality are not only associated with management, but also with the environmental context, such as temperature and precipitation (Andrews et al., 2004). We attempted to quantify physical, chemical, biological and biochemical changes as a function of different management systems in dryland mango orchards.

Perennial crops generally improve soil structure while annual vegetable crops grown either in rows or on beds and furrows often result in structural degradation mainly as a result of loss of soil organic matter and ground cover due to soil disturbance. Soil structure and aggregates are strongly influenced by processes such as tillage, cropping systems and climate. Orchard soil improvement is accelerated when ground cover is enhanced, organic matter addition is enhanced and soil is least disturbed. In this study a conventionally managed mango orchard was brought under conservation horticulture practices. This has minimised soil disturbance, enhanced the ground cover and added organic matter to the soil besides improving the micro climate leading to conservation of water and improving the micro climate. Hence the BD of the soil and soil aggregate stability has improved in conservation plots. It has been shown by several workers that aggregate stability is strongly related with soil organic carbon (Shepherd et al., 2001). A legume cover crop like Mucuna added more organic residues to the system followed by intercrop with cow pea. But in sweet potato plot a non-legume crop, available organic residue (above ground plant biomass) was small as huge biomass was removed off site through tubers. Tillage practices and low organic inputs cause rapid loss of organic carbon and stable aggregation (Lal \& Kimble, 1997) and also affect the distribution and stability of soil aggregates (Six et al., 2000). In CCVF no residue was left in the field and in CCIM only the leaf litter was available for incorporation. This was reflected in the quantitative changes in both BD and aggregate distribution of soil (Tables 2 and 4).

Infiltration rate of water is influenced by the management practices followed in orchards. It throws light on how much water will enter the root zone following a good management practice and also the attendant danger of soil erosion following runoff if the rate of infiltration is restricted due to bad management (Hillel, 1982). Conservation practices in Alfisols aid in enhancing infiltration by adding organic residues, providing more porous medium and preventing surface crust formation (Rao et al., 1998). In this study infiltration in all plots has enhanced with conservation practices. Clean cultivation in mango orchards or sole vegetable plots recorded lowest intake of water compared with mango plots with weed cover or any other inter or cover crops. Several workers (El-Swaify et al., 1985; Venkateswarlu, 1987) suggested that to enhance productivity in Alfisols such management practices should be followed which would increase infiltration and availability of water for use by crops. The rates obtained with infiltrometer remained high in plots with conservation practices viz., inter or cover crops because huge organic residues were added in to the soil. As a result, a crust did not form, porosity increased and the bulk density of the soil reduced. It is obvious that the use of heavy machines on soil coupled with loss of soil organic matter leads to soil compaction. Such compacted soils tend to have low infiltration rates (Chancellor, 1977) and encourage run off. Ben-Hur et al. (1987) found similar differences by using ring infiltrometer in Israel.

Relationship between measured IRs and selected soil properties indicated that high average IRs were observed in CHP plots (CHPM, CHPC, CHPSP, WCIM) and is attributed to high organic matter content, low bulk density values and an enhanced exchangeable basic cations. This could also be explained by the correlation values of IRs obtained in relation to the above mentioned properties as shown in Tables 11 and 12. The implication is that the variation of IRs in these areas is apparently due to variation in these properties. Rao et al. (1998) also showed that by maintaining a high soil cover the loss of rainwater as runoff in Indian Alfisols can be reduced effectively. In Nigerian Alfisols, Osuji et al. (2010) showed that tillage affect the infiltration rate of soils and the rate of such changes are related to addition of organic matter to soil and consequently their effect on the properties of soil. Therefore the amount of water available to the crops can be increased by enhancing organic residue incorporation and maintaining a soil cover. 
Table 11. Correlation and regression analysis of average steady state infiltration rates with selected soil properties

\begin{tabular}{llll}
\hline Soil property & $\mathrm{r}$ & $\mathrm{r}^{2}$ & Regression line \\
\hline Organic matter & 0.865 & 0.748 & Infiltration rate $=171.97$ Organic $\mathrm{C}-743.66$ \\
$\mathrm{BD}$ & -0.905 & 0.819 & Infiltration rate $=1192.52-769.89$ Bulk density \\
$\mathrm{pH}$ & 0.776 & 0.602 & Infiltration rate $=658.69 \mathrm{pH}-3650.326$ \\
Exchangeable bases & 0.910 & 0.828 & Infiltration rate $=14.868$ Exchangeable bases -101.37 \\
\hline
\end{tabular}

Table 12. Correlation analysis of average enzyme activities with selected soil properties

\begin{tabular}{lllll}
\hline Soil property & Dehydrogenase & Urease & Phosphomonoestrase & Arylsulphatase \\
\hline Organic matter & 0.898 & 0.888 & 0.922 & 0.921 \\
BD & 0.957 & 0.981 & 0.979 & 0.836 \\
pH & 0.887 & 0.853 & 0.940 & 0.804 \\
Exch. bases & 0.948 & 0.941 & 0.984 & 0.891 \\
AC & 0.980 & 0.938 & 0.986 & 0.836 \\
SMBC & 0.929 & 0.972 & 0.984 & 0.921 \\
CMR & 0.918 & 0.943 & 0.971 & 0.782 \\
\hline
\end{tabular}

Under conservation tillage systems with inter crops and cover crops in mango orchards, the absence/reduction of soil disturbance produced a modification of surface soil conditions, which improved soil physical properties and reduced soil organic matter decomposition. Franzluebbers et al. (1995) reported that active fractions of soil organic matter increased in superficial soil layers in no tillage compared to traditional tillage. In this study soil under conservation practices (CHPM, CHPC and CHPSP) presented higher LOI, OC, AC, WSC and SMBC contents than in soils under CCIM or CCVF (Table 5). These changes were in proportion to the amount of residues retained in the soil under each system (Table 1). Further the mineralization rates were also higher in the plots with conservation practices due to availability of easily decomposable carbon indicating enhanced availability of nutrients in addition to enhanced soil organic C (Table 5). Franzluebbers (2005) while comparing 96 plots at 22 locations, showed enhanced SOC under conventional tillage and no tillage. Hence, adoption of conservation tillage in the structurally unstable Indian Alfisols has a high potential for SOC sequestration. Under similar macroclimate and management history, the less disturbed the soil, the greater the SOC content. Increasing SOC content with fewer disturbances can be attributed to slower decomposition in the surface residue layer as a result of less favourable microclimatic conditions for microbial activity.

Change in soil organic carbon status was reflected in changes in the soil extracellular enzyme activities as well. In general dehydrogenase, urease, phosphomonoestrase and aryl sulphatase activities were higher under plots following conservation practices than under plots with conventional practices in mango or vegetable field. The rhizosphere of leguminous crops may secrete higher amounts of exudates more actively than in vegetable crops, and may therefore supply more carbon and nitrogen to the soil for enhanced microbial activity leading to enhanced levels of enzymes (Ganeshamurthy, 2009; Hazarika et al., 2013; Nuruzzaman et al., 2005). Soils under conservation tillage have been shown to have higher soil microbial biomass and enzymatic activity than those under conventional tillage systems (Madejón et al., 2007; Melero et al., 2008), indicating an activation of microorganisms through carbon source inputs from organic residues. The results showed that AC content was the best parameter that explained total variance of the data set in plots with conservation practices and clean cultivation practices, revealing the advantages of conservation tillage. Although AC content is more commonly used asthe soil quality indicator in agroecosystems (Hazarika et al., 2013; Madejón et al., 2007), this study showed that $\mathrm{AC}$ and $\mathrm{SMBC}$ contents are equally sensitive and reliable indicators for assessing the impact of different soil management systems on soil quality.

A generalization often made is that, at the micro-food web scale, zero tillage systems tend to be fungal-dominated whereas conventional tillage systems tend to be bacterial-dominated, although this could depend on whether measurements were made near the soil surface or deeper in the soil profile. This study also showed (Figure 4) that in the surface layers conservation horticultural practices led to fungal-dominance whereas 
conventional tillage systems tend to be bacterial-dominated. Simmons and Coleman (2008) attributed the difference in fungal population between zero and conventional tillage systems to the ability of an ecosystem to withst and disturbance, whereas bacterial-dominated systems are more resilient than fungal dominated systems due to the different energy pathway (Bardgett \& Cook, 1998). Moore et al. (2003) postulated that recovery times from disturbance of each energy channel may be different, and results in an alteration of the food web. Soils in zero tillage systems would evolve fungal dominated, 'slow' energy channels, while soils in conventional tillage would break down substrate via a bacterial dominated, or 'fast' energy channel (de Ruiter et al., 1998; Hendrixet al., 1986).

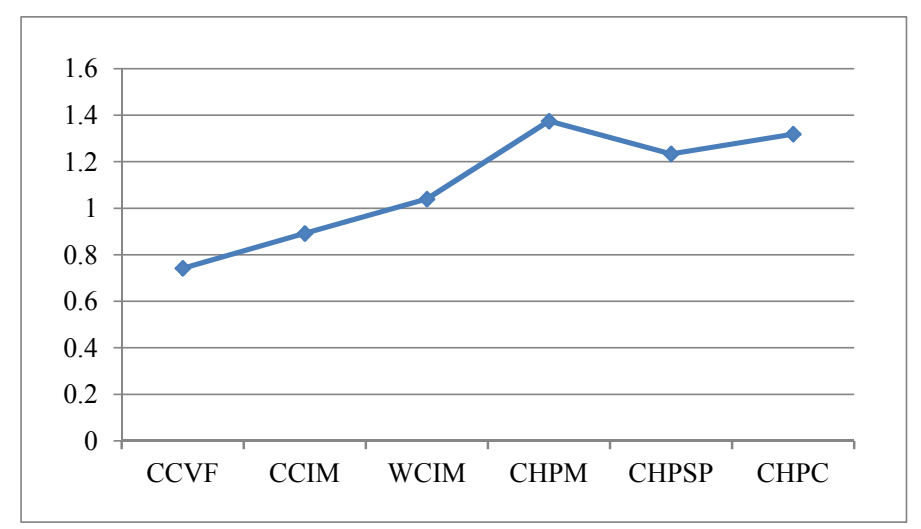

Figure 4. Ratio between bacteria and fungi in conventional and conservation plots

The use of a single enzyme may not be suitable to assess changes in soil quality mainly because enzyme activities catalyse specific reactions and they are substrate-specific. Hence we used a set of four enzymes in this study. Dehydrogenase is an oxido-reductase, which is present only in viable cells. This enzyme has been considered as a sensitive indicator of soil quality and it has been proposed as a valid biomarker to indicate changes in total microbial activity due to changes in soil management, under different agronomic practices and climates. Dehydrogenase activity responded to the treatments (Table 9) in a similar manner to the AC fraction, i.e. increasing with the adoption of no tillage, in direct proportion to the accumulation of crop residues in the soil surface (Table 5). The decomposition of such residues in soil releases essential nutrients, such as N, P and S, required for both plant and microbial growth. Tillage had negative effects on the hydrolase activities considered in this study (urease, phosphatase and sulphatase).

Fauna abundance is indicative of total number of individuals per unit area which are capable of living within the given environment (Mutema et al., 2013). If the theory that higher species richness results in higher levels of energy transfer holds, then the same can be applied when fauna abundance is higher. Macro fauna population (Table 10) was significantly higher in plots following conservation than conventional practices. This was true for all the groups; i.e. earthworms, micro arthropods and centipedes. They are basically primary shredders (Agwunobi et al., 2013) of most dry organic materials; hence their population tend to increase with increasing amounts of organic material applied as soil cover. The results also showed (Table 10) that conservation horticulture had a profound effect on macrofauna density as well as diversity. This increase in macrofauna will aid in enhancing the rate of decomposition of organic material. In the conservation horticultural systems, their abundance increased with increasing amounts of crop residues available. Earthworms and centipedes were absent in CCVF and CCIM plots indicating resource degradation in these plots and toxicity created by excessive use of agrochemicals. It appears quick and convenient to use the number of fauna groups (species richness) in assessing fauna community situations. Higher species richness would suggest a complex community with a high degree of species interaction; hence that community is capable of supporting higher levels of energy transfer, predation, competition and niche availability than other similar communities that exhibit lower species richness. The results of improved species richness upon adoption of conservation horticulture practices clearly demonstrated the significance of addition of organic residues and reduced tillage in protecting fauna activity and habitat. The addition of organic matter on soil surface further ameliorates soil conditions for better survival and support of more fauna groups. Woltering (2005) and Mutema et al. (2013) also observed similar results where soil cover in the form of crop residues increased biological activity. This is indicative of the fact that early stages 
and the primary shredders of organic matter continue to be a more active group as fresh addition of organic residues is a continuous process in conservation horticulture plots. Therefore it is important to monitor dynamics of fauna diversity and evenness in long term conservation horticulture trials.

\section{Conclusions}

Long-term soil conservation management in mango orchards improved the quality of soils through enhancing the organic carbon fraction and biological status, especially near the surface. Addition of litter and other crop residues lowered the soil bulk density and enhanced the infiltration rate. Soil aggregates and water stability improved under conservation treatments. Soil microbial diversity and extra cellular enzymes level improved over conventional management. Absence of earthworms and centipedes in vegetable plot and conventional mango orchards showed deterioration in soil properties under conventional intensive systems.

\section{Acknowledgements}

The financial support received from ICAR-National Innovations on Climate Resilient Agriculture (NICRA) is gratefully acknowledged.

\section{References}

Alf, K., \& Nannipieri, P. (1995). Cellulase activity, Methods, in Applied Soil Microbiology and Biochemistry. Academic Press, London.

Andrews, S. S., Karlen, D. L., \& Cambardella, A. (2004). The soil management assessment framework: A quantitative evaluation using case studies. Soil Sci. Soc. Am. J., 68, 1945-1962. http://dx.doi.org/10.2136/sssaj2004.1945

Bardgetta, R. D., \& Cook, R. (1998). Functional aspects of soil animal diversity in agricultural grasslands. Applied Soil Ecol., 10, 263-276. http://dx.doi.org/10.1016/S0929-1393(98)00125-5

Ben-Hur, M., Shainberg, I., \& Morin, J. (1987). Variability of infiltration in a field with surface-sealed soil. Soil Sci. Soc. Am. J., 51, 1299-1302. http://dx.doi.org/10.2136/sssaj1987.03615995005100050037x

Bouwer, H. (1986). Intake rate: Cylinder infiltrometer. In A. Klute (Ed.), Methods of Soil Analysis, Part1: Physical and Mineralogical Methods (2nd ed.). Am. Soc. Agron., and Soil Sci. Soc. Am. (pp. 825-844). Madison.

Chancellor, W. J. (1977). Compaction of soils byagricultural equipment. Division of Agric. Sci. Univ. California, Bull., 1,881 .

Chivenge, P. P., Murwira, H. K., \& Six, J. (2007). Long-term impact of reducedtillage and residue management on soil carbon stabilization: Implications for conservation agriculture on contrasting soils. Soil and Tillage Res., 94, 328-337. http://dx.doi.org/10.1016/j.still.2006.08.006

Conant, R. T., Easter, M., Paustian, \& Williams, S. (2007). Impacts of periodic tillage on soil C stocks: Asynthesis. Soil and Tillage Res., 95, 1-10. http://dx.doi.org/10.1016/j.still.2006.12.006

De Ruitera., Peter, C., Neutela, A.-M., \& Mooreb, J. C. (1998). Biodiversity in soil ecosystems: The role of energy flow \& community stability. Applied Soil Ecol., 10, 217-228. http://dx.doi.org/10.1016/S0929-1393(98)00121-8

Dospechov, B. A., Vasiljev, I. P., \& Tulikov, A. M. (1977). Practicum of methods in Agriculture (p. 367). Kolos, Moskva.

El-Swaify, S. A., Pathak, P., Rego, T. J., \& Singh, S. (1985). Soil management for optimized productivity under rainfed conditions, in the semi-arid tropics. Adv. Soil Sci., 1, 1-64. http://dx.doi.org/10.1007/978-1-4612-5046-3_1

Franzluebbers, A. J. (2005). Soil organic carbon sequestration and agricultural greenhouse gas emissions in the southeastern USA. Soil and Tillage Res., 83, 120-147. http://dx.doi.org/10.1016/j.still.2005.02.012

Franzluebbers, A. J., Hons, F. M., \& Zuberer, D. A. (1995). Soil organic carbon, microbial biomass, and mineralizablecarbon and nitrogen in sorghum. Soil Sci. Soc. Am. J., 59, 460-466. http://dx.doi.org/10.2136/sssaj1995.03615995005900020027x

Gajic, B. (2005). Soil physics laboratory manual (p. 185). Grafoprint, Zemun-Belgrade.

Ganeshamurthy, A. N. (2009). Soil changes following long-term cultivation of pulses. J. Agric. Sci., 147, 699-706. http://dx.doi.org/10.1017/S0021859609990104 
Gregorich, E. G., Carter, M. R., Angers, D. A., Monreal, C. M., \& Ellert, B. H. (1994). Towards a minimum data set to assess soil organic matter quality in agricultural soils. Can. J. Soil Sci., 74, 367-385. http://dx.doi.org/10.4141/cjss94-051

Hanway, J. J., \& Heidel, H. (1952). Soil analysis methods as used in Iowa State College. College Bull (pp. 1-36). Soil Testing Laboratory, Iowa State.

Hazarika, S., Thakuria, D., \& Ganeshamurthy, A. N. (2013). Soil quality as influenced by land use history of orchards in humid subtropics. Catena, 123, 37-44. http://dx.doi.org/10.1016/j.catena.2014.07.006

Hendrix, P. F., Parmelee, R. W., Crossley, Jr., \& Groffman, P. M. (1986). Detritus food webs inconventional and no-tillage agroecosystems. Bioscience, 36, 374-86. http://dx.doi.org/10.2307/1310259

Hillel, D. (1982). Introduction to soil physics. Academic press publishers, NY.

Jackson, M. L. (1973). Soil Chemical Analysis (p. 480). Prentice Hall, Englewood Cliff.

Lal, R., Kimble, J. M., Follett, R. F., \& Cole, C. V. (1998). The potential of U.S. cropland to sequester carbon and mitigate the greenhouse effect. Ann Arbor Press, Chelsea, MI.

Madejón, E., Moreno, F., Murillo, J. M., \& Pelegrín, F. (2007). Soil biochemical response to long-term conservationtillage under semi-arid Mediterranean conditions. Soil and Tillage Research, 94, $346-352$. http://dx.doi.org/10.1016/j.still.2006.08.010

Melero, S., Madejón, E., Herencia, J. F., \& Ruiz, J. C. (2008). Effect of implementing organic farming on chemical and biochemical properties of an irrigated loam soil. Agronomy Journal, 100, 136-144. http://dx.doi.org/10.2134/agrojnl2007.0087

Melero, S., Madejón, E., Ruiz, J. C., \& Herencia, J. F. (2007). Chemical and biochemical properties of a clay soil underdryland agriculture system as affected by organic fertilization. European Journal of Agronomy, 26, 327-334. http://dx.doi.org/10.1016/j.eja.2006.11.004

Moore, J. C., McCann, K., Setälä, H., \& De Ruiter, P. C. (2003). Top-down is bottom-up: Does predation in the rhizosphere regulate aboveground production. Ecology, 84, 857. http://dx.doi.org/10.1890/0012-9658(2003)084[0846:TIBDPI]2.0.CO;2

Nuruzzaman, M., Lambers, H., Bolland, M. D. A., \& Veneklaas, E. J. (2005). Phosphorus benefits of different legumecrops to subsequent wheat grown in different soils of Western Australia. Plant and Soil, 271, 175-187. http://dx.doi.org/10.1007/s11104-004-2386-6

Osuji, G. E., Okon, M. A., Chukwuma, M. C., \& Nwarie, I. I. (2010). Infiltration Characteristics of Soils under Selected Land Use Practices in Owerri, Southeastern Nigeria. World Journal of Agricultural Sciences, 6, 322-326.

Rao, K. P. C., Steenhuisb, T. S., Coglec, A. L., \& Smith, G. D. (1998). Rainfall infiltration and runoff from an Alfisolin semi-arid tropical India. I. No-till systems. Soil and Tillage Research, 48, 51-59. http://dx.doi.org/10.1016/S0167-1987(98)00124-X

Rapport, D. J. (1995). Ecosystem health-More than a metaphor. Environmental Values, 4, $287-309$. http://dx.doi.org/10.3197/096327195776679439

Six, J., Paustian, K., Elliott, E. T., \& Combrink, C. (2000). Soil structure and organic matter. I. Distribution of aggregate-size classes and aggregate-associated carbon. Soil Science Society of America Journal, 64, 681-689. http://dx.doi.org/10.2136/sssaj2000.642681x

Subbaiah, B. V., \& Asija, G. L. (1956). A rapid procedure for estimation of available nitrogen in soils. Current Sci., $25,259-260$.

Venkateswarlu, J. (1987). Effect of resource management systemsfor dry lands of India. Adv. Soil Sci., 7, 165-221. http://dx.doi.org/10.1007/978-1-4612-4790-6_5

Voroney, R. P., \& Paul, E. A. (1984). Determination of $\mathrm{k}_{\mathrm{C}}$ and $\mathrm{k}_{\mathrm{N}}$ in situ for calibration of the chloroform

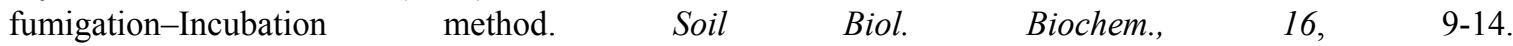
http://dx.doi.org/10.1016/0038-0717(84)90117-2

Walkley, A., \& Black, I. A. (1934). An examination of the Degtjaredd method for determining soil organic matter and proposed modification of the chromic titration method. Soil Sci., 37, 29-38. http://dx.doi.org/10.1097/00010694-193401000-00003 


\section{Copyrights}

Copyright for this article is retained by the author(s), with first publication rights granted to the journal.

This is an open-access article distributed under the terms and conditions of the Creative Commons Attribution license (http://creativecommons.org/licenses/by/3.0/). 